\title{
Bacterial Treatment and Metal Characterization of Biomedical Waste Ash
}

\author{
Shelly Heera, Kunal, and Anita Rajor \\ School of Energy \& Environment, Thapar University, Patiala, Punjab 147004, India \\ Correspondence should be addressed to Anita Rajor; anitarajor@yahoo.com
}

Received 29 May 2014; Accepted 27 July 2014; Published 13 August 2014

Academic Editor: Milva Pepi

Copyright (C) 2014 Shelly Heera et al. This is an open access article distributed under the Creative Commons Attribution License, which permits unrestricted use, distribution, and reproduction in any medium, provided the original work is properly cited.

\begin{abstract}
Biomedical waste ash generated due to the incineration of biomedical waste contains large amounts of heavy metals and polycyclic aromatic hydrocarbons (PAHs), which is disposed of in regular landfills, and results in unfavorable amounts of hazardous materials seeping into the ground and may pollute surface water and groundwater. Therefore, it is essential to remove the toxicity of ash before disposal into landfills or reutilization. Environmental characteristic analysis of BMW ash showed increased hardness $(1320 \mathrm{mg} / \mathrm{L})$ and chloride $(8500 \mathrm{mg} / \mathrm{L})$ content in leachate compared to World Health Organization (WHO) and Environment Protection Agency (EPA) guidelines for drinking water (hardness, $300 \mathrm{mg} / \mathrm{L}$; chloride, $250 \mathrm{mg} / \mathrm{L}$ ). The alkalinity and $\mathrm{pH}$ of the ash leachate were $400 \mathrm{mg} / \mathrm{L}$ and 8.35 , respectively. In this paper, study was carried out to investigate the metal tolerance level of bacterial isolates isolated from soil. The isolate Bacillus sp. KGMDI can tolerate up to $75 \mathrm{mg} / \mathrm{L}$ of metal concentration ( $\mathrm{Mn}, \mathrm{Mo}, \mathrm{Cr}, \mathrm{Fe}, \mathrm{Cu}$, and $\mathrm{Zn}$ ) in enriched growth medium. This shows that the isolated culture is capable of growing in presence of high concentration of heavy metals and acts as potential biological tool to reduce the negative impact of BMW ash on the environment during landfilling.
\end{abstract}

\section{Introduction}

Medical care is necessary for our life, health, and wellbeing, but the waste generated from medical activities can be hazardous, toxic, and even lethal because of its high potential for diseases transmission. The hazardous and toxic parts of waste from health care and research establishments are generated during diagnosis, treatment, or immunization of humans and animals or from research activities, comprising infectious, biomedical, and radioactive material. This constitutes a grave risk, if not properly treated/disposed of or allowed to get mixed with other municipal waste, and represents a real problem of living nature and human world. According to Mastorakis et al. [1], "Biomedical waste means any solid and/or liquid waste including its container and any intermediate product, which is generated during the diagnosis, treatment or immunization of human beings or animals or in research pertaining thereto or in the production or testing thereof."

India generates a huge quantity of biomedical waste (BMW) every year. According to Ministry of Environment and Forests (MoEF), Government of India, 4,05,702 kg/day of
BMW is generated of which only 2,91,983 kg/day is disposed. It means that almost $28 \%$ of the waste is left untreated and finds its way in dumps or water bodies and contaminates the environment. Thus, a proper system should be required to manage biomedical waste. Several methods have been employed but the best available technology for disposing of BMW is incineration [2]. Incinerators are deemed as favourable in this respect because they are perceived as reducing waste to one tenth of its original volume and therefore reduce the volume of waste going to landfill sites. Incineration is a high temperature thermal process involving combustion of the waste under controlled condition for converting them into inert material and gases. The large amount of ash thus generated needed to be disposed of. The landfilling of the incineration ash is the most common way for its disposal.

The excessive landfilling of the incineration ash without thinking about the detrimental effects on the environment poses a risk to groundwater contamination and threat to the nature. Heavy metals migration is a serious environmental problem and is a major topic of investigation and research. The retention and migration of heavy metals are highly 
dependent on soil $\mathrm{pH}$, presence of carbonates, the degree of saturation, and the time duration. It is usually the extremes of alkalinity and acidity that cause environmental problems, difficulty with growing plants, or groundwater contamination. If a soil has too much acid in it, the nutrients in the soil will be dissolved too quickly and leached away as the water drains. If soil is alkaline, or in other words if there is not enough acid, then nutrients will not dissolve quickly enough. Thus, a neutral soil, which is neither too acidic nor too alkaline, is the preferred type of soil for plant life to thrive.

Many studies have been reported on reducing the toxicity of the incinerator ash so that there will be minimum health risks after landfilling of ash but all the treatments employ use of chemicals which are hazardous, costly, and laborious and may affect the health of workers. Microorganisms can act as a better tool for removing the toxicity level of the incinerator ash and the best suited microorganism which can easily adapt extreme environment can help to decrease the vulnerable effects of the ash on soil and groundwater. The present study was conducted to analyze the parameters such as alkalinity, hardness, chloride, and metal content of biomedical waste ash leachate before and after bacterial treatment for sustainable environment protection.

\section{Materials and Methods}

2.1. Sample Collection. Biomedical waste ash samples were greyish black in colour and procured from the incineration point located near Dera Bassi in Punjab (India). The samples were collected in plastic bags and sealed for further use. The ash samples were fully autoclaved so that there would be no interference with the selected microorganism during treatment.

2.2. Optimization of Metal Tolerance of Isolates in an Enriched (Nutrient Broth, NB) and Minimal Medium (MM). The stock culture of two isolates, isolate I (Bacillus sp. KGMD1) and isolate II (Bacillus sp. KG5), was subcultured twice to obtain an active inoculum. The culture was incubated for $48 \mathrm{~h}$ at $37^{\circ} \mathrm{C}$ on rotary shaker at $150 \mathrm{rpm}$. Bacterial growth in minimal media was measured at $600 \mathrm{~nm}$ using spectrophotometer and stored at $4^{\circ} \mathrm{C}$ for further screening. In order to screen for metal tolerance, the isolates were grown in minimal and nutrient broth media with 25,50 , and $75 \mathrm{mg} / \mathrm{L}$ of different metal concentrations such as $\mathrm{Fe}, \mathrm{Mn}, \mathrm{Hg}, \mathrm{Mo}, \mathrm{Cu}, \mathrm{Zn}, \mathrm{Cr}, \mathrm{Pb}$, $\mathrm{Al}$, and $\mathrm{Ag}$. Isolate that shows maximum tolerance to metals was selected and the growth was measured by spectrophotometer at $\mathrm{OD}_{600}(600 \mathrm{~nm}$ wavelength).

2.3. Bacterial Treatment of BMW Ash. The ash samples were treated with selected bacterial isolate in the presence of molasses and glucose ( $0.1 \%$ conc.) as a rich carbon source and incubated at $37^{\circ} \mathrm{C}$ for 8 days. The samples from 5 treatments, namely, control ( $\mathrm{C}$, only ash), molasses + ash (MC, without microbes), molasses + ash + bacteria ( $\mathrm{MB}$, with microbes), glucose + ash (GC, without microbes), glucose + ash + bacteria (GB, with microbes), were tested periodically in triplicate for alkalinity, hardness, chloride [3], and heavy metal content.

Bacterial culture of OD 1.0 (final concentration) was taken for the treatment and centrifuged at $8000 \mathrm{rpm}$ for $10 \mathrm{~min}$ for getting the pellet. The pellet was then washed twice with distilled water and resuspended in molasses and glucose so that the final concentration of molasses and glucose in different samples should be $0.1 \%$. These solutions were added in autoclaved ash samples in such a way that the resultant mixture does not form slurry. The control ash samples consist of ash only, ash along with molasses and glucose, but no bacterial inoculation.

2.4. Analysis of the Ash Samples. During incubation, the samples of different treatments were tested periodically for important water quality parameters such as the hardness, chloride, alkalinity, and heavy metal content. Leachate of the samples was generated by mixing with water in ratio $1: 10$ and shaked vigorously at $150 \mathrm{rpm}$ for $1 \mathrm{~h}$. The supernatant was then removed from the flask and analysed for the estimation of $\mathrm{pH}$, alkalinity, chloride, and heavy metal content. All the treatments had three replications.

Heavy metal content was estimated by using inductive coupled plasma mass spectrometer (ICP-MS) after acid digestion of the leachate samples with $\mathrm{HCl}: \mathrm{HClO}_{4}: \mathrm{HNO}_{3}$ mixture. The digested sample was then diluted with $10 \% \mathrm{HNO}_{3}$ solution. Multielement standard solution of heavy metal was purchased from Sigma-Aldrich. Statistical analysis was done using Graph Pad Prism 5.0 software and represented as standard deviation.

\section{Results and Discussions}

3.1. Isolation of Metal Tolerating Microorganisms. The isolation of bacteria was done from the soil of Thapar University and grown on nutrient agar medium. The isolates were selected as they showed good growth on nutrient agar plates and then grow in minimal medium (MM) which were selected for further experimentation.

3.2. Optimisation of Metal Tolerance by Microorganisms in an Enriched (Nutrient Broth) and Minimal Media (M9). The two isolates I and II were screened for their metal tolerance capacity (Tables 1 and 2) in enriched medium and minimal medium. Table 1 shows four concentrations 10, 25, 50, and $75 \mathrm{mg} / \mathrm{L}$ of different metals in nutrient broth (NB). It was found that isolate I was found effective with aluminum (Al) and silver (Ag) as they showed maximum growth (OD 1.118 and 0.834 , resp.) after 4 days at $75 \mathrm{mg} / \mathrm{L}$ metal concentration in nutrient broth. This strain was also found to be comparatively least effective for mercury $(\mathrm{Hg})$ and copper $(\mathrm{Cu})$ as the growth after 4 days has declined to a very low level (OD 0.002 and 0.008 , resp.) at $75 \mathrm{mg} / \mathrm{L}$ metal concentration. In the case of isolate II, the maximum growth was observed in iron (Fe), 1.230, followed by molybdenum (Mo), 1.065, and the least growth was found in the cases of copper $(\mathrm{Cu})$, 0.098, and Zinc $(\mathrm{Zn}), 0.23$. Santarsiero and Ottaviani [4] estimated heavy metals in residues from hospital solid waste 
TABLE 1: Growth of microbes on different metal concentrations in nutrient broth (NB).

\begin{tabular}{lccccccccc}
\hline \multirow{2}{*}{ S. number } & \multirow{2}{*}{ Metals } & \multicolumn{9}{c}{ Isolate I } & \multicolumn{3}{c}{ Isolate II } \\
& & $10 \mathrm{mg} / \mathrm{L}$ & $25 \mathrm{mg} / \mathrm{L}$ & $50 \mathrm{mg} / \mathrm{L}$ & $75 \mathrm{mg} / \mathrm{L}$ & $10 \mathrm{mg} / \mathrm{L}$ & $25 \mathrm{mg} / \mathrm{L}$ & $50 \mathrm{mg} / \mathrm{L}$ & $75 \mathrm{mg} / \mathrm{L}$ \\
\hline$(1)$ & $\mathrm{Fe}$ & 1.547 & 0.652 & 0.78 & 0.685 & 1.474 & 0.593 & 0.987 & 1.23 \\
$(2)$ & $\mathrm{Mn}$ & 0.877 & 0.690 & 1.12 & 0.550 & 0.876 & 0.406 & 0.023 & 0.299 \\
$(3)$ & $\mathrm{Hg}$ & 0.823 & 0.799 & 0.338 & 0.002 & 0.563 & 0.304 & 0.045 & 1.007 \\
$(4)$ & $\mathrm{Mo}$ & 0.721 & 0.024 & 0.09 & 0.103 & 0.721 & 0.801 & 0.198 & 1.065 \\
$(5)$ & $\mathrm{Cu}$ & 1.117 & 1.216 & 0.567 & 0.008 & 1.117 & 1.061 & 0.43 & 0.098 \\
$(6)$ & $\mathrm{Zn}$ & 0.805 & 0.634 & 0.118 & 0.112 & 0.417 & 0.443 & 0.245 & 0.23 \\
$(7)$ & $\mathrm{Cr}$ & 0.221 & 0.429 & 0.765 & 0.089 & 0.224 & 0.068 & 0.098 & 0.652 \\
$(8)$ & $\mathrm{Pb}$ & 0.867 & 0.345 & 0.654 & 0.098 & 0.543 & 0.652 & 0.008 & 0.439 \\
$(9)$ & $\mathrm{Al}$ & 0.707 & 0.265 & 0.932 & 1.118 & 0.763 & 0.617 & 0.465 \\
$(10)$ & $\mathrm{Ag}$ & 0.654 & 0.234 & 1.09 & 0.834 & 0.943 & 0.843 & 0.102 \\
\hline
\end{tabular}

${ }^{\#}$ All values are in optical density (OD) at $600 \mathrm{~nm}$.

TABLE 2: Growth of microbes on different metal concentrations in minimal medium (M9).

\begin{tabular}{|c|c|c|c|c|c|}
\hline \multirow{2}{*}{ S. number } & \multirow{2}{*}{$\begin{array}{c}\text { Metals } \\
\text { Concentration }\end{array}$} & \multicolumn{2}{|c|}{ Isolate I } & \multicolumn{2}{|c|}{ Isolate II } \\
\hline & & $25 \mathrm{mg} / \mathrm{L}$ & $50 \mathrm{mg} / \mathrm{L}$ & $25 \mathrm{mg} / \mathrm{L}$ & $50 \mathrm{mg} / \mathrm{L}$ \\
\hline (1) & $\mathrm{Fe}$ & 0.76 & 0.598 & 0.56 & 0.575 \\
\hline (2) & $\mathrm{Mn}$ & 0.43 & 1.705 & 0.62 & 0.733 \\
\hline (3) & $\mathrm{Hg}$ & 0.43 & 0.080 & 0.87 & 0.064 \\
\hline (4) & Mo & 0.62 & 1.559 & 0.63 & 0.174 \\
\hline (5) & $\mathrm{Cu}$ & 0.31 & 0.623 & 0.92 & 0.258 \\
\hline (6) & $\mathrm{Zn}$ & 0.02 & - & 0.73 & 0.549 \\
\hline (7) & $\mathrm{Cr}$ & 0.12 & - & 0.09 & 0.087 \\
\hline (8) & $\mathrm{Pb}$ & 0.23 & 0.210 & 0.03 & 0.098 \\
\hline (9) & $\mathrm{Al}$ & 0.65 & 0.117 & 0.92 & 0.612 \\
\hline (10) & Ag & 0.34 & 0.302 & 0.89 & 0.714 \\
\hline
\end{tabular}

${ }^{\#}$ All values are in optical density (OD) at $600 \mathrm{~nm}$.

incineration and found huge quantity of metals present in the ash.

As nutrient broth is an enriched medium, the metal tolerance capacity of the two isolates was checked in minimal media (M9) also. The tolerance level was found to be $50 \mathrm{mg} / \mathrm{L}$ of different metal concentrations. The maximum tolerance (Table 2) was found with manganese $(\mathrm{Mn})$ which was 1.705 and molybdenum (Mo) as 1.559 and zinc $(\mathrm{Zn})$ and chromium $(\mathrm{Cr})$ showed no growth after 4 days. The isolate II showed maximum growth with $\mathrm{Al}$ and $\mathrm{Ag}$ as 0.612 and 0.714 , respectively, at $50 \mathrm{mg} / \mathrm{L}$ metal concentration and the growth was totally declined in case of $\mathrm{Cr}$ and $\mathrm{Hg}$. The growth of bacteria is depending upon several factors such as temperature and $\mathrm{pH}$, and tolerance to metal concentration that can be metabolized in the metabolic activity of bacteria. Due to toxicity conditions in the ash, there was not fixed pattern in the growth of bacteria at different concentration of metals (Table 2). This data shows that both of the isolates were good for the removal of metals from the biomedical waste ash leachate.
3.3. Morphological Characterization of Isolate I. After analyzing the metal tolerance level of the two selected isolates, isolate I was selected for further experiments. The isolate I was Gram +ve, rod shaped, and growing aerobically. The isolate was able to hydrolyze starch and gelatin and exhibited the catalase and citrate test. It showed characteristic utilization of the carbohydrate substrates: glucose, sucrose, and lactose. Other biochemical characteristics of the isolate I are shown in detail in Table 3. On the basis of morphological, biochemical analysis, isolate I is identified as Bacillus sp. KGMD1.

3.4. Effect of pH on Growth of Bacterial Isolate I. Each organism has a $\mathrm{pH}$ range within which growth is possible. Most organisms have $\mathrm{pH}$ optimum in the range of 5-9. Very few species can grow at $\mathrm{pH}$ values below 2 or above 10 . Organisms capable of living at low $\mathrm{pH}$ are called acidophiles. Those capable of living at very high $\mathrm{pH}$ are called alkaliphiles.

Initially, at $\mathrm{pH} 6$, the growth of the isolate I was observed by measuring the optical density at $600 \mathrm{~nm}$ and it had shown OD 0.3 , and, as the $\mathrm{pH}$ is increased, the growth increased linearly up till it reaches pH 10 (OD 1.3) and then OD showed a slight decrease till $\mathrm{pH} 12$ and afterwards got totally declined to 0.45 at $\mathrm{pH} 14$ (Figure 1). This graphical representation clearly indicated that the optimum $\mathrm{pH}$ level is $10-12$ and is highly suitable for alkaline type of environment.

3.5. Hardness, Alkalinity, and Chloride Content in BMW Ash Leachate. In alkalinity tests, there were $33 \%$ reduction in alkalinity of BMW ash leachate after 5 days of treatment in which molasses was used as a carbon source and 38.8\% reduction when glucose was used as a carbon source, whereas there was no considerable amount of reduction in control experiments (Table 4 ). There was $22.4 \%$ (glucose as a carbon source) and $14.7 \%$ (molasses as a carbon sources) reduction in hardness which was observed. It means glucose acted as readily available carbon source for the microbes during treatment of the ash. On the 2nd day, the value has reached down to $1040 \mathrm{mg} / \mathrm{L}$ from $1290 \mathrm{mg} / \mathrm{L}$ and, on the 5 th day, the value has sufficiently decreased to $1000 \mathrm{mg} / \mathrm{L}$. 
TABLE 3: Morphological and biochemical characteristics of the bacterial isolate I. $(+)$ denotes presence of growth and (-) denotes absence of growth.

\begin{tabular}{lc}
\hline Morphological test & Isolate I \\
\hline Gram staining & Positive \\
Shape (Rod/Cocci) & Small rods \\
Form & Irregular \\
Colonies & White opaque \\
\hline Biochemical test & Isolate I \\
\hline Citrate utilization test & + \\
Starch hydrolysis test & + \\
\hline Biochemical test & Isolate I \\
\hline Gelatin test & + \\
Catalase test & + \\
\hline Carbohydrate utilization & + \\
\hline Glucose & + \\
Sucrose & + \\
Lactose & + \\
\hline
\end{tabular}

Also, the chloride content of the treated BMW ash leachate after 5 days showed sufficient amount of decrease $61.0 \%$ in the case of glucose and $56.76 \%$ in the case of molasses (Table 4). The control treatment showed no considerable decrease indicating that the microbes were responsible for reducing the various parameters of the leachate and reduced its toxicity.

Leachate analysis of ash by using APHA standard methods proved that there is reduction in 50\% alkalinity, $25 \%$ hardness, and $60 \%$ chloride within 5 days of treatment compared to control when suitable carbon source (glucose and molasses) along with bacterial isolate was inoculated.

The treatment of the BMW ash with bacterium had given some positive response. As glucose is an easily available carbon source, it can be easily metabolized by the bacteria as compared to molasses that contains several sugars (such as glucose, fructose, saccharose, and raffinose) which may or may not be readily utilized by the bacteria. This reduction in the alkalinity may impart less negative impact on environment in terms of groundwater, surface water, and soil contamination.

3.6. Heavy Metal Analysis of BMW Ash Leachate. When molasses was used as a carbon source for the biological treatment of the BMW ash leachate, there was comparatively less reduction in heavy metals toxicity as compared to the case in which glucose was used as a carbon source (Table 5). In case of aluminium, maximum retention (50\%) was found in the isolate when glucose as carbon source was used and, in the case of molasses, there was only $10 \%$ retention. The chromium content in BMW ash leachate was comparatively very high and, after 10-day treatment with the selected isolate, the results had shown considerable amount of decrease (42\%) in the case of glucose as a carbon source. Lead, which is highly poisonous in nature, was also taken up by the microbes in

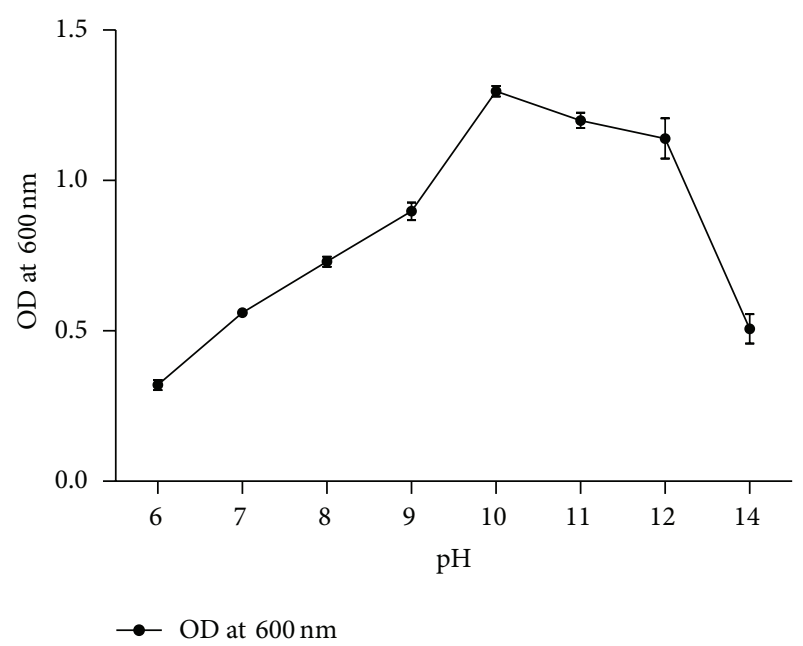

FIGURE 1: Growth of bacterial strain in MM at different $\mathrm{pH}$.

a sufficient amount (57\%) after treatment and this case had shown better results. Silver metal had shown the least amount of retention as compared to others as there was only $7.4 \%$ decrease. It means the uptake of silver metal by the isolate was not that efficient as compared to others.

The treatment of the ash by the use of the isolate I showed positive response on the reduction of the toxicity level of the heavy metals. There is $50 \%, 42 \%, 57 \%$, and $40 \%$ reduction in $\mathrm{Al}, \mathrm{Cr}, \mathrm{Pb}$, and $\mathrm{Ag}$ content when $0.1 \%$ glucose was used as a carbon source and $10 \%, 32 \%, 60 \%, 60 \%$ reduction in $\mathrm{Al}$, $\mathrm{Cr}, \mathrm{Pb}, \mathrm{Ag}$ content when $0.1 \%$ molasses was used as a carbon source.

Valavanidis et al. [5] also studied on metal leachability, polycyclic aromatic hydrocarbons, and polychlorinated biphenyls in fly ash and bottom ash of biomedical waste incinerator ash and maximum metals were removed by leachability. The selected isolate might have different mechanisms to respond to the contaminants. Studies reported that the bacterial isolate can bind the metal ions present in the medium at the cell surface or absorbed them into the cells and detoxified them through metabolic processes [6-8]. It is possible that the selected isolates may use more than one mechanism to remove metal ions like biosorption (adsorption of metal ions onto the cell surface without requirement of energy) or bioaccumulation (absorption of metal ions into the cells with an energy requirement). It is likely that biosorption would be the main mechanism that the biomass could use in the absence of an energy demanding accumulation inside the cells.

Anjum et al. [9] performed the combined leaching of selected metals from incinerated hospital waste (HW) bottom ash using ultrasonic and microbial treatment. Energy dispersive X-ray (EDX) analysis showed the presence of $\mathrm{Na}, \mathrm{K}, \mathrm{Ca}$, $\mathrm{Fe}$, and $\mathrm{Al}$ elements in HW bottom ash with a concentration range of $22-115 \mathrm{~g} / \mathrm{kg}$ whereas heavy metals such as $\mathrm{Cu}, \mathrm{Cr}, \mathrm{Ni}$, $\mathrm{Sn}$, and $\mathrm{Ti}$ were present in the range of $0.51-21.74 \mathrm{mg} / \mathrm{kg}$. It was observed that citric and oxalic acid produced by fungi (Aspergillus niger) were the leaching agents that dissolve the metals. Leaching of metals was at its maximum when 


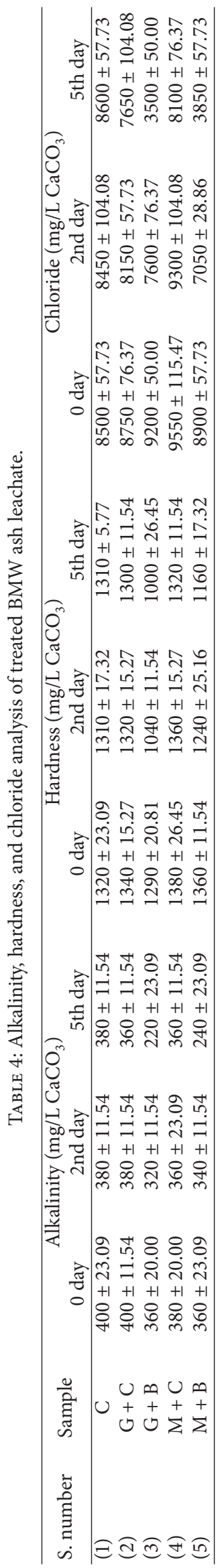


TABLE 5: ICP-MS analysis of the BMW ash leachate after treatment (in mg/L).

\begin{tabular}{lcccccc}
\hline Metals & C (only ash) & M + B (1st day) & M + B (10th day) & G + B (1st day) & G + B (10th day) & WHO standards \\
\hline $\mathrm{Al}$ & $9.54 \pm 0.08$ & $8.46 \pm 0.12$ & $7.55 \pm 0.19$ & $10.45 \pm 0.14$ & $7.12 \pm 0.14$ & 5.0 \\
$\mathrm{Cr}$ & $5.99 \pm 0.13$ & $4.64 \pm 0.01$ & $3.18 \pm 0.09$ & $4.58 \pm 0.16$ & $2.62 \pm 0.12$ & 2.0 \\
$\mathrm{~Pb}$ & $0.88 \pm 0.01$ & $0.53 \pm 0.02$ & $0.27 \pm 0.01$ & $0.78 \pm 0.15$ & $0.33 \pm 0.02$ & 0.1 \\
$\mathrm{Ag}$ & $2.64 \pm 0.12$ & $2.77 \pm 0.01$ & $2.55 \pm 0.06$ & $2.22 \pm 0.12$ & $1.91 \pm 0.12$ & 1.2 \\
\hline
\end{tabular}

bioleaching was combined with ultrasonic treatment after 9 days of treatment. It was concluded that leaching of metals was much higher in citric and oxalic acid than in other acids. These findings supported the results of present study where after 10 days of treatment lower values of metal were observed after bacterial treatment (Table 5).

$\mathrm{Xu}$ and Ting [10] optimized the conditions for bioleaching of heavy metals from municipal solid waste (MSW) incinerator fly ash. They investigated the sucrose concentration, inoculum spore concentration, fly ash pulp density, and the time of addition of fly ash to the fungus Aspergillus niger to achieve the maximum metal leaching efficiency for selected metals. Results showed that the concentration of $\mathrm{Al}, \mathrm{Fe}$, $\mathrm{Zn}$, citric acid, and gluconic acid attained in the leached liquor was $12.3,12.3,77.6 \mathrm{ppm}, 51$, and $281 \mathrm{mM}$, respectively, and mainly depends more upon the sucrose concentration and pulp density than spore concentration and the time of addition of the fly ash. Similarly, Yang et al. [11] observed that bioleaching efficiency of MSW incinerator ash was the highest for $\mathrm{Cd}$ (93.06\%) followed by $\mathrm{Mn}, \mathrm{Pb}$, and $\mathrm{Zn}(70 \%)$ and 22,33 , and $47 \%$ for $\mathrm{Fe}, \mathrm{Cr}$, and $\mathrm{Cu}$, respectively, using A. niger as bioleaching agent. Toxicity characteristic leaching procedure (TCLP) results of MSW ash bioleaching showed that the leaching toxicities of treated ash were far lower than the permissible limits of China.

\section{Conclusion and Further Scope}

Ash analysis and characterization of incinerator ash are an important tool to predict the behaviour of ash during the biological treatment of specific waste ash and also the reactivity of ash during its disposal in landfill areas or its use as a base material for construction purpose. During landfilling, the leachate from the ash may create groundwater and surface water contamination due to high alkalinity, hardness, chloride, and heavy metals content. The reduction in the alkalinity, hardness, chloride, and heavy metals content after treatment with isolate I imparts less negative impact on environment in terms of groundwater, surface water, and soil contamination.

The future aspect would be dependent on using both of the strains to obtain a higher percentage of HMs removal and on increasing the exposure time (incubation period) and biomass dose including the use of optimal conditions for $\mathrm{pH}$ and temperature.

\section{Conflict of Interests}

The authors declare that there is no conflict of interests regarding the publication of this paper.

\section{References}

[1] N. E. Mastorakis, C. A. Bulucea, T. A. Oprea, and P. Dondon, "Holistic approach of biomedical waste management system with regard to health and environmental risks," International Journal of Energy and Environment, vol. 5, pp. 309-318, 2011.

[2] A. Rajor, M. Xaxa, R. Mehta, and Kunal, "An overview on characterization, utilization and leachate analysis of biomedical waste incinerator ash," Journal of Environmental Management, vol. 108, pp. 36-41, 2012.

[3] APHA, AWWA, and WEF, Standard Methods for Examination of Water and Waste Water, American Public Health Association, Washington, Wash, USA, 21st edition, 2005.

[4] A. Santarsiero and M. Ottaviani, "Evaluation of heavy metals in slags from medical waste incinerator," Microchemical Journal, vol. 51, no. 1-2, pp. 166-169, 1995.

[5] A. Valavanidis, N. Iliopoulos, K. Fiotakis, and G. Gotsis, "Metal leachability, heavy metals, polycyclic aromatic hydrocarbons and polychlorinated biphenyls in fly and bottom ashes of a medical waste incineration facility," Waste Management and Research, vol. 26, no. 3, pp. 247-255, 2008.

[6] E. V. Ariskina, A. V. Vatsurina, N. E. Suzina, and E. Y. Gavrish, "Cobalt- and chromium-containing inclusions in bacterial cells," Microbiology, vol. 73, no. 2, pp. 159-162, 2004.

[7] M. Gavrilescu, "Removal of heavy metals from the environment by biosorption," Engineering in Life Sciences, vol. 4, no. 3, pp. 219-232, 2004.

[8] N. Mallick, "Copper-induced oxidative stress in the chlorophycean microalga Chlorella vulgaris: response of the antioxidant system," Journal of Plant Physiology, vol. 161, no. 5, pp. 591597, 2004.

[9] F. Anjum, M. Shahid, S. Bukhari, and J. H. Potgieter, "Combined ultrasonic and bioleaching treatment of hospital waste incinerator bottom ash with simultaneous extraction of selected metals," Environmental Technology, vol. 35, no. 1-4, pp. 262-270, 2014.

[10] T. J. Xu and Y. P. Ting, "Optimisation on bioleaching of incinerator fly ash by Aspergillus niger-use of central composite design," Enzyme and Microbial Technology, vol. 35, no. 5, pp. 444-454, 2004.

[11] J. Yang, Q. H. Wang, J. Xue, and S. Tian, "Influence of fly ash concentrations on the growth of Aspergillus niger and the bioleaching efficiency of heavy metals," Huanjing Kexue, vol. 29, no. 3, pp. 825-830, 2008. 

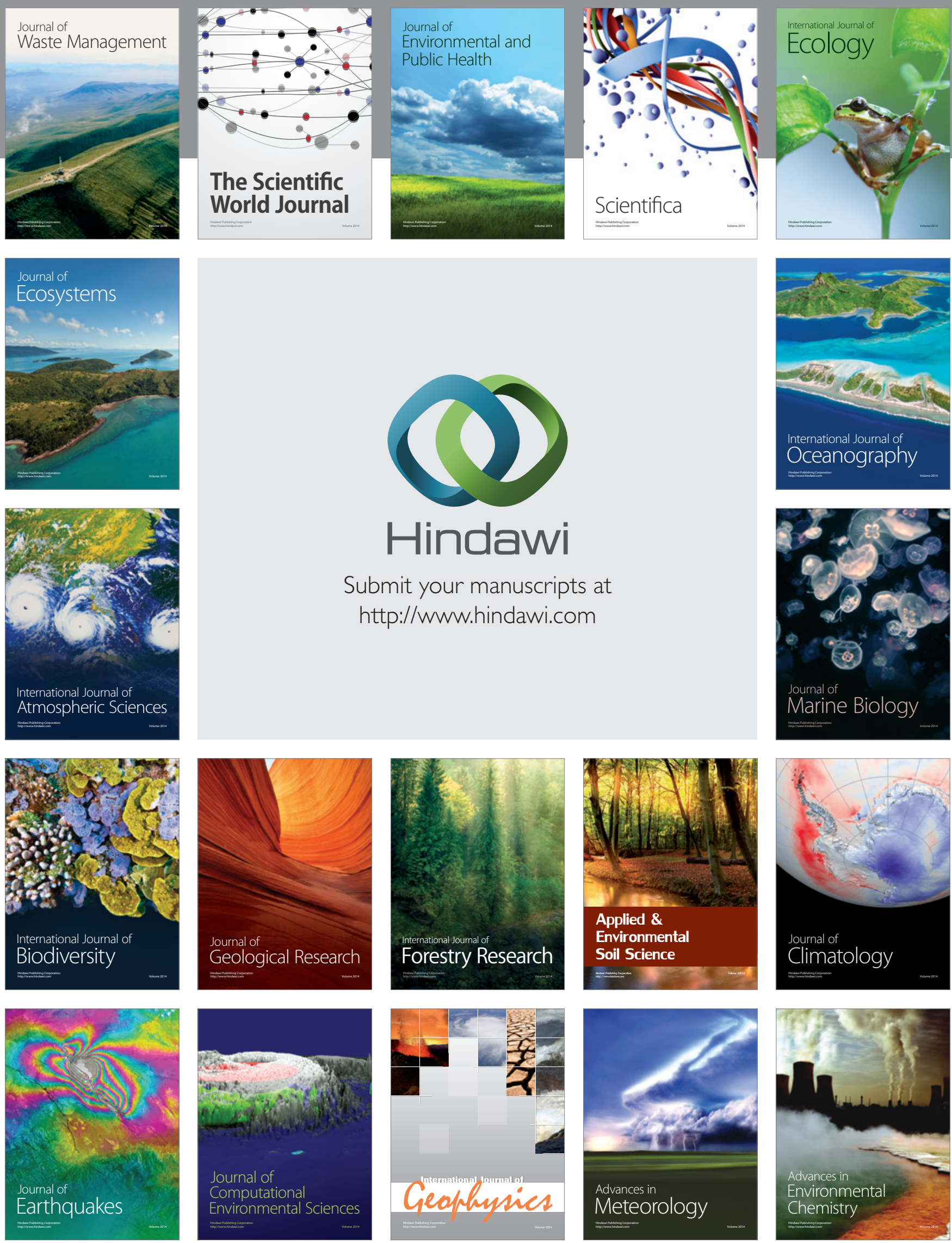